\title{
Adalimumab for ulcerative colitis: results of a Brazilian multicenter observational study
}

\author{
Patrícia ZACHARIAS ${ }^{1}$, Aderson Omar Mourão Cintra DAMIÃO², Antonio Carlos MORAES ${ }^{3}$, \\ Fábio Vieira TEIXEIRA4 ${ }^{4}$, Juliano Coelho LUDVIG ${ }^{5}$, Rodrigo Bremer NONES ${ }^{6}$, Rogerio SAAD-HOSSNE7, \\ Ligia Yukie SASSAKI ${ }^{8}$, Rosemary Pereira Lino da SILVA', Luiza FACCHIN1, \\ Marcia OLANDOSKI ${ }^{9}$ and Paulo Gustavo KOTZE' ${ }^{1}$
}

Received 15/6/2017 Accepted 29/6/2017

\begin{abstract}
Background - Adalimumab is a monoclonal antibody, tumor necrosis factor-alpha (TNF $\alpha$ ) inhibitor that has efficacy for inducing and maintaining remission in moderate-to-severe ulcerative colitis. Real world studies with adalimumab in Latin American ulcerative colitis patients are scarce. Objective - To assess the clinical remission rates in induction and maintenance with adalimumab therapy in ulcerative colitis. Methods - Observational, multicenter and retrospective study on a case series of patients with moderate-to-severe ulcerative colitis under adalimumab therapy. The variables analyzed were: demographic data, previous infliximab status, concomitant drugs, the Montreal Classification, disease activity (Mayo score) at weeks 0 , 8, 26 and 52, or until the last follow-up. Clinical remission was defined as a partial Mayo score $\leq 2$ and Last observation carried forward (LOCF) and Non responder imputation (NRI) analysis were used. Results - Thirty-six patients were included in the study. With LOCF analysis, remission rates at weeks 8,26 e 52 were of $41.7 \%, 47.2 \%$ and $47.2 \%$, respectively. With NRI analysis, remission rates at weeks 8,26 and 52 were of $41.7 \%, 41.7 \%$ and $27.8 \%$, respectively. Conclusion - Adalimumab was effective in the treatment of moderate-to-severe ulcerative colitis. Clinical remission was observed in approximately $40 \%$ of the patients at weeks 8 and 26, and in almost a quarter of the patients after 1 year of follow up.
\end{abstract}

HEADINGS - Proctocolitis. Ulcerative colitis. Adalimumab. Inflammatory bowel diseases.

\section{INTRODUCTION}

Ulcerative colitis (UC) is an inflammatory disease of the large bowel with variable degree of activity, extent and disease course ${ }^{(3)}$. Up to $15 \%$ of patients can present with severe disease at diagnosis ${ }^{(7,30)}$ and in up to $28 \%$ it can progress proximally in 10 years ${ }^{(16,30)}$. Most patients have a recurrent and remitting disease course with periodic flares, in which intravenous corticosteroids and eventually colectomy can be necessary ${ }^{(3,6)}$. Treatment with tumor necrosis factor (TNF) inhibitor agents can be used in moderate-to-severe $\mathrm{UC}$, refractory to conventional treatment with aminosalicylates and immunomodulators and/or in steroid-dependent patients ${ }^{(4,17)}$.

The most commonly used anti-TNF agents are infliximab (IFX) and adalimumab (ADA). IFX, a chimeric monoclonal antibody, has proven efficacy in UC in pivotal trials ACT 1 and 2, in induction and maintenance of remission in moderate-to-severe UC, as well as reducing the need for colectomy ${ }^{(21,22,24)}$. As all biological agents, IFX can be immunogenic, thus infusion reactions and secondary loss of response, related to antibodies to the drug may be a relevant problem ${ }^{(11)}$.

ADA is a fully human monoclonal antibody and recombinant immunoglobulin $\mathrm{G} 1(\mathrm{IgG} 1)^{(2)}$. This drug was approved by regulatory agencies after proven efficacy in ULTRA I and II trials ${ }^{(19,20,23,25)}$.
The rate of colectomy in ULTRA II trial was less than 5\%, without stratification regarding the previous use of another anti-TNF agent $^{(8)}$. The drug was approved by Food and Drug Administration (FDA) and National Sanitary Surveillance Agency (ANVISA), in 2012 and 2014, respectively ${ }^{(14)}$.

Despite the results of the clinical trials, there is a discrepancy between those and real world data in $\mathrm{UC}^{(15)}$, similar to what was observed in terms of efficacy of ADA in Crohn's disease (CD) ${ }^{(13)}$. Retrospective studies of case series tend to have higher effectiveness rates than randomized trials, which have a more strict analysis. Furthermore, it is enquired what the ideal dose of ADA in the management of $\mathrm{UC}$ would be needed ${ }^{(12)}$, showing the need of data from real life studies to better define the drug's role in treatment algorithms. There is scarce real world data on the use of ADA in $\mathrm{UC}$ reported in Brazil and Latin America, which motivated the present study ${ }^{(1,2,9,10,18,28,29)}$.

The primary aim of this study was to analyze clinical remission rates in ADA induction and maintenance in UC treatment. Secondary objectives were to analyze clinical response, endoscopic remission, colectomy rates, adverse events, and secondary loss of response, besides dose optimization or drug switching during the follow-up period.

Declared conflict of interest of all authors: Damião AOMC (Nestle, Janssen, Abbvie, Pfizer and Takeda), Moraes AC (Janssen, Abbvie, Takeda), Teixeira FV (Janssen, Abbvie, Ferring, Takeda, Pfizer), Ludvig JC (Janssen, Abbvie, Takeda), Nones RB (Abbvie, Takeda), Saad-Hossne R (Janssen, Abbvie), Sassaki LY (Janssen, Abbvie, Takeda), Kotze PG (Janssen, Abbvie, Ferring, Takeda, Pfizer)

Disclosure of funding: no funding received

Study carried out at Unidade de Cirurgia Colorretal, Hospital Universitário Cajuru, Universidade Católica do Paraná (PUCPR), Curitiba, PR, Brasil.

${ }^{1}$ Unidade de Cirurgia Colorretal, Hospital Universitário Cajuru, PUCPR, Curitiba, PR, Brasil; 2 Serviço de Gastroenterologia da FMUSP, São Paulo, SP, Brasil; ${ }^{3}$ Serviço de Gastroenterologia do Hospital Clementino Fraga Filho, UFRJ, Rio de Janeiro, RJ, Brasil, ${ }^{4}$ Clínica Gastrosaúde, Marília, SP, Brasil· 5 Clínica ESADI, Blumenau, SC, Brasil: 6 Servico de Gastroenterologia, Hospital Nossa Senhora das Graças, Curitiba, PR, Brasil; ${ }^{7}$ Departamento de Cirurgia Digestiva, UNESP, Botucatu, SP, Brasil; ${ }^{8}$ Serviço de Gastroenterologia, UNESP, Botucatu, SP, Brasil; ${ }^{9}$ Disciplina de Bioestatística, PUCPR, Curitiba, PR, Brasil.

Correspondence: Paulo Gustavo Kotze. Rua Mauá, 682 - CEP: 80030-200 - Curitiba, PR, Brasil. E-mail: pgkotze@hotmail.com 


\section{METHODS}

\section{Study design}

This was a longitudinal, analytical, observational and retrospective study of a case series of patients with moderate-to-severe UC under ADA therapy. All patients were treated in seven referral centers for inflammatory bowel disease (IBD) from south/southeast Brazil, and were analyzed from August 2014 to October 2016.

\section{Inclusion and exclusion criteria}

The inclusion criteria were: patients with moderate-to-severe UC (Mayo score $>6$ ) that used subcutaneous ADA in regular doses (160 $\mathrm{mg}$ at week 0 and $80 \mathrm{mg}$ at week 2 as induction, followed by $40 \mathrm{mg}$ every 2 weeks for maintenance therapy, with dose optimization to weekly after induction, if necessary according to physicians' individual perception). All individuals included were treated as outpatients, were between 18 and 80 years of age, and were refractory to conventional therapy. The exclusion criteria were: patients with undetermined inflammatory bowel disease (UIBD) or with diagnosis of Crohn's disease (CD), besides patients with severe UC admitted to the hospital. Patients under 18 and over 80 years old, patients who underwent colorectal surgery previously or those in use of other biologic agents were also excluded.

\section{Variables analyzed}

The variables analyzed were: gender, age at UC diagnosis, extent of disease according to the Montreal Classification ${ }^{(27)}$, disease duration from diagnosis to the beginning of biological therapy, smoking status, use of corticosteroids at the beginning of ADA, concomitant use of immunomodulators and previous use of IFX. In addition, the degree of disease activity, as defined by the Mayo score, was evaluated at weeks $0,8,26$ and 52, or until the latest follow-up visit. The Mayo score is a classification used to determine disease severity, as detailed in Figure $1^{(26)}$. Mild disease is defined as

\begin{tabular}{|c|l|l|l|l|}
\hline Score & $\begin{array}{l}\text { Stool } \\
\text { frequency* }\end{array}$ & $\begin{array}{l}\text { Rectal } \\
\text { bleeding } \dagger\end{array}$ & $\begin{array}{l}\text { Findings on } \\
\text { endoscopy }\end{array}$ & $\begin{array}{l}\text { Physician's } \\
\text { global } \\
\text { assessment }\end{array}$ \\
\hline 0 & $\begin{array}{l}\text { Normal } \\
\text { number of } \\
\text { stools for this } \\
\text { patient }\end{array}$ & No blood seen & $\begin{array}{l}\text { Normal or } \\
\text { inactive disease }\end{array}$ & Normal \\
\hline 1 & $\begin{array}{l}1-2 \text { stools } \\
\text { more than } \\
\text { normal }\end{array}$ & $\begin{array}{l}\text { Streaks of } \\
\text { blood with } \\
\text { stool less than } \\
\text { half the time }\end{array}$ & $\begin{array}{l}\text { Mild disease } \\
\text { (erythema, } \\
\text { decreased } \\
\text { vascular pattern, } \\
\text { mild friability) }\end{array}$ & Mild disease \\
\hline 2 & $\begin{array}{l}3-4 \text { stools } \\
\text { more than } \\
\text { normal }\end{array}$ & $\begin{array}{l}\text { Obvious } \\
\text { blood with } \\
\text { stool most the } \\
\text { time }\end{array}$ & $\begin{array}{l}\text { Moderate } \\
\text { disease (marked } \\
\text { erythema, absent } \\
\text { vascular pattern, } \\
\text { friability, } \\
\text { erosions) }\end{array}$ & $\begin{array}{l}\text { Moderate } \\
\text { disease }\end{array}$ \\
\hline 3 & $\begin{array}{l}\text { stools more } \\
\text { than normal }\end{array}$ & $\begin{array}{l}\text { Blood alone } \\
\text { passed }\end{array}$ & $\begin{array}{l}\text { Severe disease } \\
\text { (spontaneous } \\
\text { bleeding, } \\
\text { ulceration) }\end{array}$ & Severe disease \\
\hline
\end{tabular}

FIGURE 1. Mayo scoring System for Assessment of UC Activity. *Each patient served as his or her own control to establish the degree of abnormality of the stool frequency.

$\uparrow$ The daily bleeding score represented the most severe bleeding of the day. $\ddagger$ The physician’s global assessment acknowledged the three other criteria, the patient's daily record of abdominal discomfort and general sense of well-being, and other observations, such as physical findings and the patient's performance status. Adapted from Schroeder et al. ${ }^{(26)}$.
Mayo score between 2 and 6, moderate-to-severe disease between 6 and 12 points. Mucosal healing was evaluated according to the endoscopic Mayo sub-score. The need for colectomy during followup, secondary loss of response (with dose optimization rates or drug switching for other biological agents) and presence and type of adverse events were also analyzed.

\section{Definitions}

Clinical remission was defined as a partial Mayo score $\leq 2$. Clinical response was defined as a reduction of partial Mayo score by 2 or more points between the beginning of treatment and certain periods of follow-up. Endoscopic remission or mucosal healing was defined as Mayo endoscopic sub-score $\leq 1$. Primary loss of response was defined as lack of clinical improvement after the induction period. Secondary loss of response was defined as the need for one of the following outcomes during treatment: colectomy, dose optimization for weekly ADA or drug switching.

\section{Statistical methods}

A shared database was used to collect demographic and clinical characteristics with the use of Excel spreadsheets, Microsoft Office software package, 2013. The results of the variables of the study were described with the mean, medium, minimum, maximum value and standard deviation (quantitative variables) or as frequency and percentage (categorical variables). The Wilcoxon non-parametric test was used to compare the initial and last assessments of the Mayo endoscopic sub-score. The colectomy free time and the need for switch of medication were described with the use of KaplanMeier curves. The clinical remission and clinical response rates were analyzed with the NRI (non-responder imputation) and LOCF methods (last observation carried forward). In the NRI method, patients with a shorter follow-up time were considered to be failures in the later periods of analysis. On the other hand, in the LOCF evaluation, the lastly evaluated information was carried forward, and it served as a value for the subsequent periods. $P$ values $<0.05$ were considered as statistical significant. Data were analyzed by using the SPSS Statistics v.20 software package.

\section{Ethical considerations}

This study was approved by the Research Ethics Committee of the Catholic University of Paraná (PUCPR) and the other institutions involved, with reference report number 009181/2016, via the Ministry of Health's website Plataforma Brasil.

\section{RESULTS}

A total of 36 patients who used ADA for treatment of UC were included in this analysis. The baseline characteristics of all analyzed patients are described in detail in Table 1. As observed, the mean age at diagnosis was 40.7 years (17-77). The majority of patients had extensive colitis and long-term disease (average disease duration of 80 months). Approximately one third of the patients $(n=14)$ had received IFX therapy previously. Of the total number of cases, $91.7 \%$ had used corticosteroids at the initiation of ADA therapy and two-thirds were using concomitant azathioprine (AZA) during ADA treatment. The mean baseline partial Mayo score was $6.6( \pm 2.2)$ and the mean endoscopic baseline sub-score was $2.5( \pm 0.7)$. 
TABLE 1. Baseline characteristics of the 36 patients included in the analysis

\begin{tabular}{lc}
\hline Characteristic & Total $(\mathrm{n}=36)$ \\
\hline $\begin{array}{l}\text { Age at diagnosis (years } \pm \text { SD) } \\
\text { Disease duration at ADA therapy initiation } \\
\text { (months; mean, min-max) }\end{array}$ & $40.7 \pm 16.6$ \\
Gender (n/\%) & $80.3(12-192)$ \\
Female & \\
Male & $17(47.2)$ \\
Montreal (n/\%) & $19(52.8)$ \\
E1 & \\
E2 & $2(5.6)$ \\
E3 & $7(19.4)$ \\
Smoking (n/\%) & $27(75)$ \\
Steroids at initiation of ADA (n/\%) & $2(5.6)$ \\
Concomitant azathioprine (n/\%) & $33(91.7)$ \\
Previous IFX (n/\%) & $24(66.7)$ \\
Follow-up period with ADA (months; mean, & $14(38.9)$ \\
min.-max.) & $12.6(2-26)$ \\
\hline
\end{tabular}

SD: standard deviation; Min: minimum; Max: maximum; IFX: infliximab; ADA: adalimumab.

\section{Primary outcome}

Clinical remission (partial Mayo score $\leq 2$ ) was observed in $41.7 \%$ of the cases at week 8 and in $47.2 \%$ at weeks 26 and 52, according to the LOCF analysis. In the NRI analysis, clinical remission was observed in $41.7 \%$ of the patients at weeks 8 and 26 and in $27.8 \%$ at week 52. These data are demonstrated in detail in Figure 2.

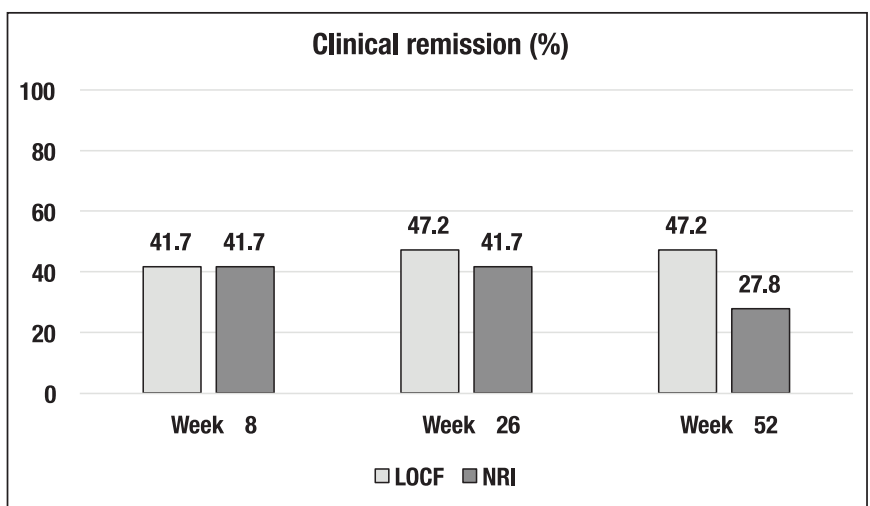

FIGURE 2. Percentage of patients with clinical remission at weeks 8 , 26 and 52. LOCF: last observation carried forward. NRI: non-responder imputation.

Comparing the clinical remission rates between IFX naïve patients $(n=22)$ with those who previously used IFX $(n=14)$, it was observed that remission in the biological naïve patients was more prevalent in absolute numbers, 50\% (11/22) versus 28.5\% (4/14). No statistical analysis was used for that comparison because of the small sample in the subgroups.

\section{Secondary outcomes \\ - Clinical response}

More than half of the patients had clinical response (partial Mayo score drop $\geq 2$ points) at week 8 , after ADA induction treatment (55.6\% by LOCF and NRI analyses). There was a gradual increase in the response rate at weeks 26 and 52 by LOCF and a decrease by the NRI methods. These data are illustrated in detail in Figure 3. At the end of the 52 weeks, $47.2 \%$ of the patients maintained clinical response, according to the NRI analysis.

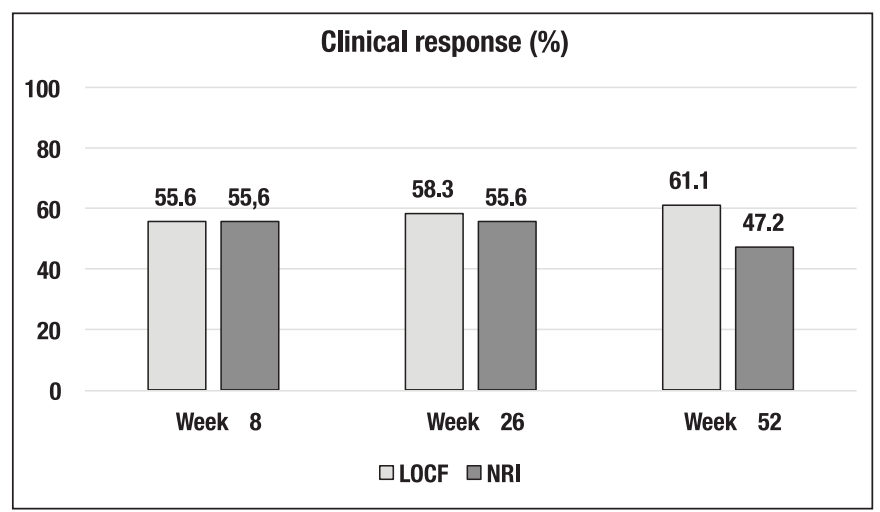

FIGURE 3. Percentage of patients with clinical response at weeks 8 , 26 and 52. LOCF: last observation carried forward. NRI: non-responder imputation.

\section{- Endoscopic remission}

One third of the patients (12/36) had endoscopic remission, defined as Mayo endoscopic sub-score $\leq 1$, in follow-up colonoscopy after the beginning of treatment. The mean time to perform the first colonoscopy was 8.4 months $( \pm 3.5)$. One of the patients in endoscopic remission had a flexible sigmoidoscopy after total colectomy with ileorectal anastomosis due to therapeutic failure.

\section{- Secondary loss of response}

The secondary loss of response to ADA was observed in half of the patients (18/36) during follow-up (7/14 patients with previous use of IFX and 11/22 naïve patients). These patients required ADA dose optimization or drug switching. Optimization of ADA therapy for a weekly dosing was required in 8 patients among which three switched to other therapies later on. Thus, switching to another biological agent was observed in 11 cases and that usually took place in the first semester of treatment (Figure 4). Five of them switched to IFX, 4 to vedolizumab and 2 to etrolizumab.

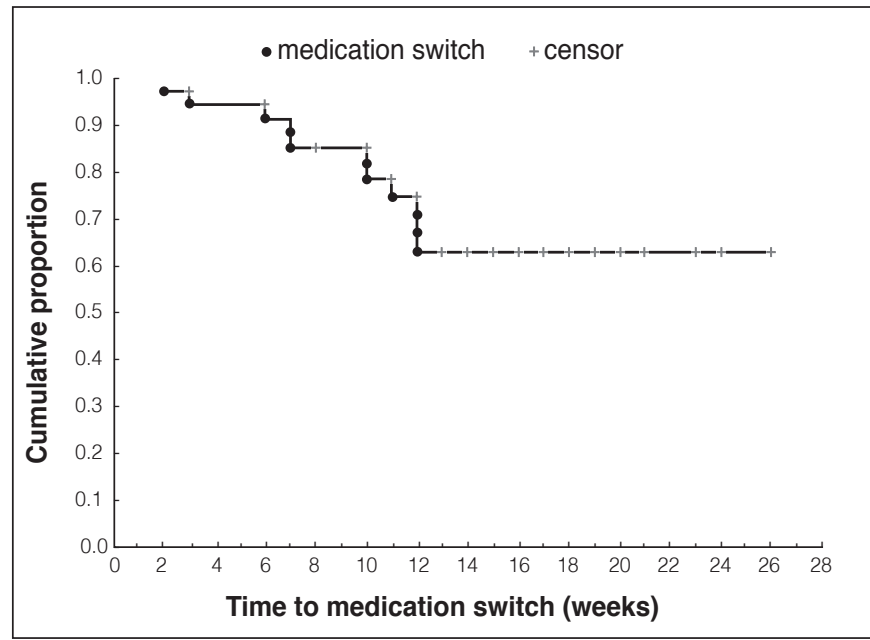

FIGURE 4. Cumulative probability of continued adalimumab therapy during follow-up. 


\section{- Colectomy rates}

Six patients from the total sample underwent colectomy during follow-up due to therapeutic failure $(16.7 \%)$. Half of the surgical patients had previously used IFX (3/6). Figure 5 demonstrates the analysis of colectomy rates according to the follow-up time (Kaplan-Meier curve). As seen, all patients had their surgical procedures during the first semester of treatment.

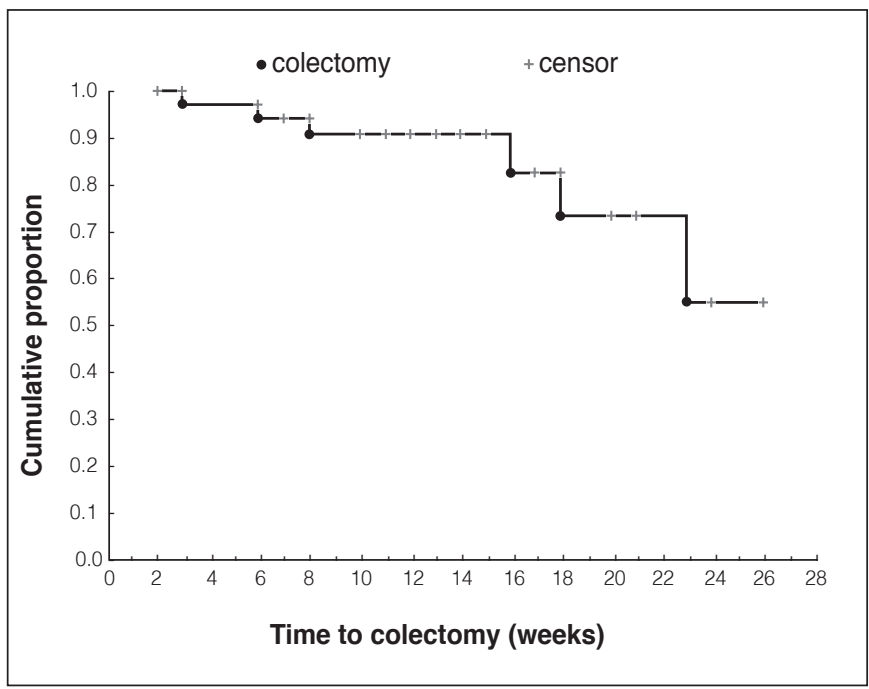

FIGURE 5. Cumulative probability of colectomy-free time under adalimumab therapy.

\section{- Safety}

The main adverse events described in the study are detailed in Table 2. Most of the adverse events were related to infections. There was no mortality in the present study, and only one patient presented malignancy (a basal cell skin carcinoma), which was locally excised without significant clinical consequences.

TABLE 2. Summary of adverse events during adalimumab treatment

\begin{tabular}{lc}
\hline Adverse events & Overall $(\mathrm{n}=36)$ \\
\hline Most common infections $(\mathrm{n} / \%)$ & $17(47.2 \%)$ \\
Urinary tract infection & $6(16.7 \%)$ \\
Sinusitis & $5(13.9 \%)$ \\
Pneumonia & $4(11.1 \%)$ \\
Other infections (n/\%) & $5(13.9 \%)$ \\
Herpes zoster & $1(2.8 \%)$ \\
Perianal abscess & $1(2.8 \%)$ \\
Gastroenteritis & $1(2.8 \%)$ \\
Tonsillitis & $1(2.8 \%)$ \\
Parotitis & $1(2.8 \%)$ \\
Local injection reaction $(\mathrm{n} / \%)$ & $2(3.6 \%)$ \\
Skin reaction (n/\%) & $3(8.3 \%)$ \\
Other (basal cell carcinoma) & $1(2.8 \%)$ \\
\hline
\end{tabular}

\section{DISCUSSION}

This retrospective multicenter study described the efficacy and safety of ADA in patients with moderate-to-severe UC, refractory to conventional therapy, from seven referral centers in IBD from south/southeast Brazil. It is the first Latin American study to demonstrate the effectiveness and safety profile of ADA in UC to date. Most of the evaluated patients had long-term disease, extensive colitis and used corticosteroids in the initiation of ADA treatment. One-third of the patients had previously taken IFX. These characteristics emphasize a population of patients with extensive and refractory disease.

In this analysis, the clinical remission rates were $41.7 \%$ at week 8 (LOCF and NRI methods); and 47.2\% (LOCF) and 27.8\% (NRI) at week 52 . The drop in the clinical remission rates with the NRI analysis was expected, as patients with a shorter follow-up were considered to be failures in the later periods of our study. This is a more conservative analysis, which tends to minimize the results. In pivotal trials, clinical remission rates were lower as compared to our results, $18.5 \%$ at week 8 (ULTRA I) ${ }^{(19)} ; 16.5 \%$ and $17.3 \%$ at week 8 and 52, respectively (ULTRA II) ${ }^{(25)}$. This variation of 10 points between these studies and ours could be explained by the differences in clinical remission definition, which considered the cases with Mayo score $\leq 2$ at the present study and was restricted to the cases with Mayo score $\leq 2$ without any subscore $>1$, in the pivotal trials. Therefore, having a less strict definition of remission may have been the cause of the higher rate in the present study as compared to the randomized trials $\mathbf{s}^{(19,25)}$. Real-life studies often show better results than pivotal studies, as they tend not to be so strict as compared to prospective trials.

In a case series, Tursi et al. reported high rates of clinical remission in patients with moderate-to-severe UC, refractory to IFX. At week 52, all patients (15 cases) were in remission ${ }^{(29)}$, unlike the rates described in the literature and in the present study $(1,2,28)$. It was expected that clinical remission rates in this study could be lower as most of the sample comprised patients with previous IFX exposure and with extensive disease (pancolitis) ${ }^{(29)}$. However, the score used to define clinical remission in this Italian study was the Crohn's disease activity index (CDAI). This made it difficult to compare it with the partial Mayo score that is used in most of the studies in UC. This was an important limitation of the study mentioned above.

A second Italian multicenter study with a larger sample of patients reported lower rates of clinical remission ${ }^{(2)}$. The rates were $17 \%$ and $28.4 \%$ at weeks 4 and 12 , respectively ${ }^{(2)}$, lower than the rates at week 8 in our study, which was $41.7 \%$. The induction dose in the Italian group was heterogeneous, $160 / 80 \mathrm{mg}$ of ADA in 17 patients and $80 / 40 \mathrm{mg}$ of ADA in 11 patients. That may have been the reason for lower remission rates in the short term. In this study, the long-term remission rate was $43.2 \%$ at week $54^{(2)}$, which was similar to those $47.2 \%$ (LOCF) demonstrated in our study, at week 52. Similarly, patients included in this multicenter Italian study had extensive (pancolitis) and long disease duration. However, most of the patients $(78.4 \%)$ had previous use of IFX, unlike our study, in which only $38.9 \%$ had previous exposure to this agent.

Regarding clinical response, our study reported a rate of 55.6\% at week 8 , similar to pivotal trials, $54.6 \%$ (ULTRA I) and 50.4\% (ULTRA II) $^{(19,25)}$. At week 52, clinical response was observed in $61.1 \%$ of the cases, with the LOCF method. On the other hand, with the NRI method, it decreased to $47.2 \%$, a less expressive drop 
than the findings of ULTRA II $(30.2 \%)^{(25)}$. Garcia et al., in a Spanish multicenter study, obtained higher rates of clinical response $(70.8 \%)$, which may have been justified by the later assessment of induction, at week 12 . However, the rate decreased to $35 \%$ (LOCF) at week 54 , in disagreement with the findings of our study with the same method $(61.1 \%)$ at week $52^{(9)}$.

In an American study, Afif et al. demonstrated less than half of the clinical response rate found at our study, at week 8 . This might be due to stricter definition of response, which included a decrease in rectal bleeding $\geq 1$. Despite of this, the rate increased at week $24(50 \%)$, similarly to the data from our analysis ${ }^{(1)}$. An indirect comparison between the present study and the main real world studies from the international literature regarding clinical remission and response, as well as colectomy rates, is shown in detail in Table 3.

The endoscopic remission rate at the present study was $33.3 \%$, with colonoscopy performed in the mean time of 8.4 months (week 33) after the initiation of ADA treatment, which was similar to the literature. In the ULTRA II study, the rates reported at week 8 were higher $(41.1 \%)$, which decreased to $25 \%$, at week $52^{(25)}$. Afif et al. observed the highest endoscopic remission rates, $49.1 \%$ after an average of 44 weeks with use of $\mathrm{ADA}^{(1)}$.

In our study, half of the patients lost clinical response during follow-up, with dose optimization to ADA weekly being required in eight cases. On the other hand, Balint et al. observed lower loss of response rates, $9.1 \%$ at week $30^{(3)}$. Among those who remained in response (34.1\%), 8.3\% lost response at week 52 . The drug was optimized in $17.8 \%$ of the cases ${ }^{(3)}$. In the Spanish study, dose optimization was observed in $37.5 \%$ of the cases, among which $14.3 \%$ did not respond even after ADA weekly intake ${ }^{(9)}$.

From the patients included in our analysis, 16.6\% (6/36) underwent colectomy during ADA treatment, similarly to the findings from a Canadian study, which observed colectomy rates in $12 \%$ of the cases ${ }^{(10)}$. The small number of colectomies in ULTRA II trial did not allow adequate comparison to our data in terms of surgical outcomes ${ }^{(25)}$. Colectomy rates were heterogeneous in the international literature (12 to $46.2 \%)^{(2,9,10,18,28)}$. A French study revealed the highest colectomy rates $(46.2 \%)^{(18)}$. In this sample, most of the patients had extensive colitis and long-term disease, similarly to the findings of our study. However, the entire sample was composed of patients that had used IFX before ${ }^{(18)}$. Therefore, higher colectomy rates may be explained by the fact that the sample was composed of refractory patients. Taxonera et al. reported lower colectomy rates $(20 \%)$ in a study with similar baseline characteristics to the French study ${ }^{(28)}$. This demonstrates the heterogeneity of findings in the literature.

In regards to the variables associated with an increase in colectomy rates, Armuzzi et al. observed that only the exposure to immunomodulators was a significant risk factor. The previous exposure to IFX also increased colectomy rates as compared to naive patients ( $29 \%$ vs $10.5 \%$ ), although no significant statistical difference was demonstrated ${ }^{(2)}$.

There are many adverse events related to anti-TNF agents, from mild to severe, and in certain cases the drug must be discontinued or switched. At the present study the overall adverse events rate was $67.9 \%$, mainly due to infections. There was a predominance of respiratory infections in our sample of patients. Only one patient developed a non-melanoma skin cancer. None of these patients stopped treatment due to adverse events. In ULTRA I, II and III trials, the rate of serious adverse events remained constant at 19\%, $12 \%$ and $17.7 \%$, respectively ${ }^{(5,19,25)}$. ADA therapy discontinuation occurred in only $10.7 \%$ in the ULTRA III trial ${ }^{(5)}$. On the other hand, Afif et al. obtained the highest serious adverse events rates $(30 \%)$, leading nine patients to stop ADA treatment $(45 \%)$. However, there was no mortality and none of the adverse events was considered to be drug-related ${ }^{(1)}$.

TABLE 3. Indirect comparison of remission, response and colectomy rates between the main retrospective studies from different countries with the present sample of patients

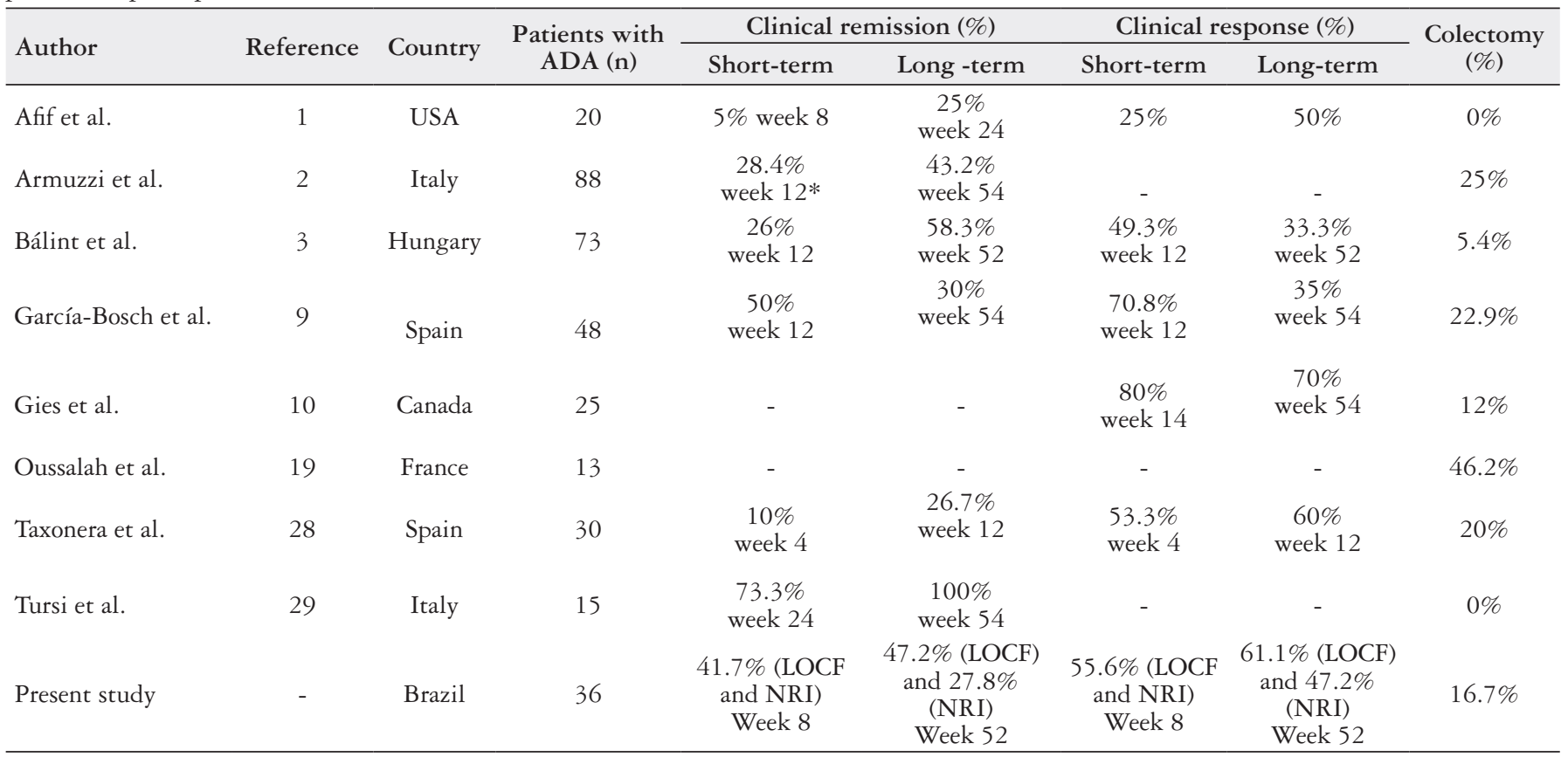

ADA: adalimumab; LOCF: last observation carried forward; NRI: non-responder imputation. 
This study had clear limitations that must be considered during the interpretation of its results. It was a retrospective study with limited number of cases, from IBD referral centers, with more severe and refractory patients. Moreover, many patients did not complete the 52-week period needed for a full evaluation. In these cases, the use of the NRI and LOCF methods, may have contributed to the estimated results.

In summary, ADA demonstrated efficacy and safety in the treatment of moderate-to-severe UC. Clinical remission was observed in approximately $40 \%$ of the patients at week 8 and at week 26 , and in nearly a quarter of the patients after one year of follow-up. Clinical response was observed in approximately $50 \%$ of the cases. One-third of the patients had reached endoscopic remission. There were significant rates of secondary loss of response to ADA, followed by dose optimization or drug switching. Colectomy was required in $16.6 \%$ of all patients. The safety profile observed was similar to that described in the literature. This was the first Latin American study performed on patients with ADA in UC.

\section{Authors' contributions}

Kotze PG, Zacharias P and Facchin L designed the study. All authors except for Olandoski $\mathrm{M}$ did data collection and were involved in patient care. Olandoski $\mathrm{M}$ did the statistical analysis. Zacharias $\mathrm{P}$ and Kotze PG drafted the article and all authors gave final revision and permission for publication.

Zacharias P, Damião AOMC, Moraes AC, Teixeira FV, Ludvig JC, Nones RB, Saad-Hossne R, Sassaki LY, Silva RPL, Facchin L, Olandoski M, Kotze PG. Adalimumabe no manejo da retocolite ulcerativa inespecífica: resultados de um estudo multicêntrico observacional brasileiro. Arq Gastroenterol. 2017;54(4):321-7.

RESUMO - Contexto - O adalimumabe é um anticorpo monoclonal, inibidor do TNF alfa, que tem eficácia comprovada na indução e manutenção da remissão na retocolite ulcerativa inespecífica moderada à severa. Há escassez de dados sobre o uso do adalimumabe na retocolite ulcerativa inespecífica em pacientes latino-americanos. Objetivo - Analisar as taxas de remissão clínica na indução e manutenção do tratamento da retocolite ulcerativa inespecífica com adalimumabe. Métodos - Estudo observacional, multicêntrico e retrospectivo de uma série de casos de portadores de retocolite ulcerativa inespecífica moderada à grave que utilizaram adalimumabe. Variáveis analisadas: dados demográficos, uso prévio de infliximabe, medicações concomitantes, Classificação de Montreal, atividade da doença (escore parcial de Mayo) nas semanas 0, 8, 26 e 52, ou até o maior tempo de seguimento atingido. Remissão clínica foi definida como escore parcial de Mayo $\leq 2 \mathrm{e}$ foi avaliada pelos métodos. Abordagem com base na observação mais recente (LOCF) e Imputação de não respondedores (NRI). Resultados - Trinta e seis pacientes foram incluídos no estudo. Pela análise LOCF, as taxas de remissão nas semanas 8,26 e 52 foram de 41,7\%, 47,2\% e 47,2\%, respectivamente. Pela análise NRI, as taxas nas semanas 8,26 e 52 foram de $41,7 \%$, $41,7 \%$ e 27,8\%, respectivamente. Conclusão - Adalimumabe foi eficaz no manejo da retocolite ulcerativa inespecífica moderada a grave. A remissão clínica foi observada em cerca de $40 \%$ dos pacientes nas semanas 8 e 26, e em cerca de $1 / 4$ dos pacientes após 1 ano de seguimento.

DESCRITORES - Proctocolite. Colite ulcerativa. Adalimumabe. Doenças inflamatórias intestinais.

\section{REFERENCES}

1. Afif W, Leighton JA, Hanauer SB, Loftus EV Jr, Faubion WA, Pardi DS, et al Open-label study of adalimumab in patients with ulcerative colitis including those with prior loss of response or intolerance to infliximab. Inflamm Bowel Dis. 2009;15:1302-7.

2. Armuzzi A, Biancone L, Daperno M, Coli A, Pugliese D, Annese V, et al. Adalimumab in active ulcerative colitis: A "real-life" observational study. Dig Liver Dis. 2013;45:738-43.

3. Bálint A, Farkas K, Palatka K, Lakner L, Miheller P, Rácz I, et al. Efficacy and safety of adalimumab in ulcerative colitis refractory to conventional therapy in routine clinical practice. J Crohn's Colitis. 2016;10:26-30

4. Christensen KR, Steenholdt C, Brynskov J. Clinical outcome of adalimumab therapy in patients with ulcerative colitis previously treated with infliximab A Danish single-center cohort study. Scand J Gastroenterol. 2015;50:1018-24.

5. Colombel JF, Sandborn WJ, Ghosh S, Wolf DC, Panaccione R, Feagan B, et al. Adalimumab maintains remission for up to 4 years in patients with ulcerative colitis. Gastroenterology. 2014;146:589-90.

6. Cosnes J, Gower-Rousseau C, Seksik P, Cortot A. Epidemiology and natural history of inflammatory bowel diseases. Gastroenterology. 2011;140:1785-94.

7. Dignass A, Eliakim R, Magro F, Maaser C, Chowers Y, Geboes K, et al. Second European evidence-based consensus on the diagnosis and management of ulcerative colitis part 1: definitions and diagnosis. J Crohns Colitis. 2012;6:965-90.

8. Feagan BG, Sandborn WJ, Lazar A, Thakkar RB, Huang B, Reilly N, et al. Adalimumab therapy is associated with reduced risk of hospitalization in patients with ulcerative colitis. Gastroenterology. 2014;146:110-8.

9. García-Bosch O, Gisbert JP, Cañas-Ventura À, Merino O, Cabriada JL, García-Sánchez V, et al. Observational study on the efficacy of adalimumab for the treatment of ulcerative colitis and predictors of outcome. J Crohn's Colitis. 2013;7:717-22.
10. Gies N, Kroeker KI, Wong K, Fedorak RN. Treatment of ulcerative colitis with adalimumab or infliximab: long-term follow-up of a single-centre cohort. Aliment Pharmacol Ther. 2010;32:522-8.

11. Hanauer SB, Wagner CL, Bala M, Mayer L, Travers S, Diamond RH, et al. Incidence and importance of antibody responses to infliximab after maintenance or episodic treatment in Crohn's disease. Gastroenterology. 2004;2:542-53.

12. Kornbluth AA. Adalimumab: another treatment option for moderate-to- severe UC. Gastroenterol Hepatol. 2013;9:321.

13. Kotze PG, Abou-Rejaile VR, Uiema LA, Olandoski M, Sartor MC, Miranda $\mathrm{EF}$, et al. Adalimumab for maintenance therapy for one year in Crohn's disease: results of a Latin American single-center observational study. Arq Gastroenterol. 2014;51:39-45

14. Kotze PG, Albuquerque IC, Moraes AC, Vieira A, Souza F. Cost-minimization analysis with Infliximab (IFX) and Adalimumab (ADA) for the treatment of Crohn's disease (CD). Rev Bras Coloproct. 2009;29:158-68.

15. Levesque BG, Sandborn WJ, Ruel J, Feagan BG, Sands BE, Colombel JF. Converging goals of treatment of inflammatory bowel disease from clinical trials and practice. Gastroenterology. 2015;148:37-51.

16. Magro F, Rodrigues A, Vieira AI, Portela F, Cremers I, Cotter J, et al. Review of the disease course among adult ulcerative colitis population-based longitudinal cohorts. Inflamm Bowel Dis. 2012;18:573-83.

17. Nielsen $\mathrm{OH}$, Ainsworth MA. Tumor necrosis factor inhibitors for inflammatory bowel disease. N Engl J Med. 2013;369:754-62.

18. Oussalah A, Laclotte C, Chevaux JB, Bensenane M, Babouri A, Serre A, et al Long-term outcome of adalimumab therapy for ulcerative colitis with intolerance or lost response to infliximab: a single-centre experience. Aliment Pharmacol Ther. 2008;28:966-72. 
19. Reinisch W, Sandborn WJ, Hommes DW, D’Haens G, Hanauer S, Schreiber S, et al. Adalimumab for induction of clinical remission in moderately to severely active ulcerative colitis: results of a randomised controlled trial. Gut. 2011;60:780-7.

20. Reinisch W, Sandborn WJ, Panaccione R, Huang B, Pollack PF, Lazar A, et al. 52-week efficacy of adalimumab in patients with moderately to severely active ulcerative colitis who failed corticosteroids and/or immunosuppressants. Inflamm. Bowel Dis. 2013;19:1700-9.

21. Reinisch W, Sandborn WJ, Rutgeerts P, Feagan BG, Rachmilewitz D, Hanauer $\mathrm{SB}$, et al. Long-term infliximab maintenance therapy for ulcerative colitis: the ACT-1 and -2 extension studies. Inflamm Bowel Dis. 2012;18:201-11.

22. Rutgeerts P, Sandborn WJ, Feagan BG, Reinisch W, Olson A, Johanns J, et al. Infliximab for induction and maintenance therapy for ulcerative colitis. N Engl J Med. 2005;353:2462-76.

23. Sandborn WJ, Colombel JF, D'Haens G, Van Assche G, Wolf D, Kron M, et al. One-year maintenance outcomes among patients with moderately-to-severely active ulcerative colitis who responded to induction therapy with adalimumab: sub- group analyses from ULTRA 2. Aliment Pharmacol Ther. 2013;37:204-13.

24. Sandborn WJ, Rutgeerts P, Feagan BG, Reinisch W, Olson A, Johanns J, et al. Colectomy rate comparison after treatment of ulcerative colitis with placebo or infliximab. Gastroenterology. 2009;137:1250-60.
25. Sandborn WJ, Van Assche G, Reinisch W, Colombel JF, D’Haens G, Wolf DC, et al. Adalimumab induces and maintains clinical remission in patients with moderate-to-severe ulcerative colitis. Gastroenterology. 2012;142:257-65.

26. Schroeder KW, Tremaine WJ. Coated oral 5-aminosalicylic acid therapy for mildly to moderately active ulcerative colitis. A randomized study. $\mathrm{N}$ Engl J Med. 1987;317:1625-9.

27. Silverberg M, Satsangi J, Ahmad T, Arnott, I, Bernstein CN, Brant SR, et al. Toward an integrated clinical, molecular and 339 serological classification of inflammatory bowel disease: report of a Working Party of the 2005 Montreal World Congress of Gastroenterology. Can J Gastroenterol. 2005;19 Suppl A:5-36A.

28. Taxonera C, Estelles J, Fernandez-Blanco I, Merino O, Marın-Jimenez I, Barreiro-de Acosta M, et al. Adalimumab induction and maintenance therapy for patients with ulcerative colitis previously treated with infliximab. Aliment Pharmacol Ther. 2011;33:340-8.

29. Tursi A, Elisei W, Picchio M, Penna A, Forti G, Giorgetti GM, et al. Effectiveness of adalimumab for ambulatory ulcerative colitis patients after failure of infliximab treatment: a first 'real-life' experience in primary gastroenterology centers in Italy. Ann Gastroenterol. 2014;27:369-73.

30. Ungaro R, Mehandru S, Allen PB, Peyrin-Biroulet L, Colombel JF. Ulcerative colitis. Lancet. 2017;389:1756-70. 